\title{
Pengaruh Profitabilitas, Likuiditas, Pertumbuhan Penjualan Terhadap Struktur Modal (Studi Empiris Perusahaan Sektor Industri Dasar Dan Kimia Di Bursa Efek Indonesia Tahun 2016-2019)
}

\author{
Herliana Vivi Septiana ${ }^{1}$, Mohamad Zulman Hakim ${ }^{2}$, Dirvi Surya Abbas ${ }^{3}$ \\ Universitas Muhammadiyah Tangerang ${ }^{1,2,3}$ \\ email korespondensi: Herlianavivis@gmail.com
}

\begin{abstract}
Abstrak: Tujuan dari penelitian ini adalah untuk mengetahui pengaruh Profitabilitas, Likuiditas, Pertumbuhan Penjualan terhadap Struktur Modal pada perusahaan sektor Industri Dasar dan Kimia yang terdaftar di Bursa Efek Indonesia (BEI). Dengan periode yang digunakan adalah 4 tahun yaitu 2016-2019. Populasi penelitian ini mencakup seluruh perusahaan industri dasar dan kimia yang terdaftar di Bursa Efek Indonesia (BEI) 2016-2019. Teknik pengambilan sampel menggunakan teknik purposive sampling. Pada penelitian ini dari jumlah populasi sebanyak 80 perusahaan sektor industry dasar dan kimia yang terdaftar di Bursa Efek Indonesia tahun 2016-2019 hanya 26 perusahaan dipilih menjadi sampel yang telah memenuhi persyaratan. Metode analisis yang digunakan adalah analisis regresi data panel. Hasil penelitian menunjukan bahwa secara parsial profitabilitas (ROE) dan pertumbuhan penjualan tidak berpengaruh terhadap struktur modal. Sedangkan likuiditas berpengaruh negatif terhadap struktur modal

Kata kunci: Profitabilitas, Likuiditas, Pertumbuhan Penjualan, Struktur Modal
\end{abstract}

Struktur modal dapat digunakan sebagai alat dalam menentukan dan mempertimbangkan pendanaan untuk periode perusahaan yang akan datang. Struktur modal dapat menunjukkan tingkat resiko suatu perusahaan dimana ketika semakin tinggi rasio struktur modal, maka semakin tinggi resikonya bagi perusahaan karena pendanaan dari unsur hutang lebih besar dari modal sendiri. (Dahlena, 2017).

Menurut Pecking Order Theory bahwa perusahaan cenderung akan menggunakan pendanaan internal yang dari laba perusahaan yang berupa laba ditahan apabila perusahaan memiliki profitabilitas yang tinggi. Berdasarkan teori ini, terdapat hierarki penggunaan sumber dana yaitu penggunaan dana internal terlebih dahulu, kemudian jika dana internal tidak memadai, pendanaan perusahaan akan berasal dari penggunaan hutang dan pilihan yang terakhir yaitu penerbitan saham (Husnan 2012:278 dalam Apsari dan Dana 2018).

Direktur Keuangan WTON mengatakan bahwa, kenaikan utang ini searah dengan pengembangan yang dilakukan perusahaan. Rasio keuangan juga dinilai belum begitu mengkhawatirkan. Saat ini tingkat perbandingan utang perusahaan terhadap ekuitas atau tingkat debt to equity ratio (DER) dinilai masih terjaga di level 0,68 kali. Utang WTON mencapai $162 \%$ menjadi Rp 5,74 triliun dari tahun sebelumnya $\mathrm{Rp} 2,19$ triliun. Utang ini berkaitan dengan kewajiban jangka pendek dan kewajiban jangka panjang. Melihat pada laporan keuangan per Juni 2019, total kewajiban WTON mencapai Rp 5,69 triliun, mengalami penurunan dari akhir Desember 2018 yakni Rp 5,74 triliun. Kewajiban ini terdiri dari kewajiban jangka pendek Rp 5,54 triliun dan kewajiban jangka panjang Rp 
153,28 miliar. Direktur keuangan WIKA Beton mengatakan bahwa, kenaikan utang ini sejalan dengan naiknya belanja modal (capital expenditure/capex) perusahaan. Sebagai gambaran, tahun 2018 pembelanjaan modal perusahaan senilai $\mathrm{Rp} 428$ miliar, tahun ini mengalami kenaikan menjadi $\mathrm{Rp} 779$ miliar. Dana belanja modal digunakan untuk keperluan investasi pembangunan pabrik dan lainnya. Tahun 2019 ini perusahaan juga akan melepaskan saham treasuri yang jumlahnya sebesar $4,33 \%$ atau setara dengan 377 juta unit saham. (https://investasi.kontan.co.id, 2019)

Profitabilitas merupakan kemampuan perusahaan dalam menghasilkan laba (keuntungan) selama periode tertentu. (Septiani dan Suaryana, 2018). Perusahaan yang memiliki tingkat profitabilitas yang tinggi akan mengurangi ketergantungan pada pihak eksternal perusahaan karena keuntungan perusahaan yang tinggi mempunyai kemungkinan perusahaan mendanai perusahaannya sendiri melalui laba ditahan (Dharmadi dan Putri, 2018). Hasil penelitian dari Deviani dan Sudjarni (2018) menyatakan bahwa profitabilitas berpengaruh signifikan negatif terhadap struktur modal dan, menurut Apsari dan Dana (2018) menyatakan bahwa profitabilitas berpengaruh signifikan terhadap struktur modal. Sedangkan menurut Septiani dan Suaryana (2018) profitabilitas tidak berpengaruh terhadap struktur modal.

Menurut Dahlena (2017), likuiditas merupakan kemampuan perusahaan dalam memenuhi kewajibannya. Semakin besar rasio likuiditas, maka akan semakin besar kemampuan perusahaan dalam memenuhi kewajibannya. Menurut Septiani dan Suaryana (2018) perusahaan yang mempunyai likuiditas tinggi cenderung akan menurunkan total utang, sehingga struktur modal akan menurun. Perusahaan yang likuiditasnya tinggi, biasanya akan menggunakan sumber dana internal seperti laba ditahan sebelum menggunakan sumber dana eksternal, seperti utang atau menerbitkan saham baru. Septiani dan Suaryana (2018), dalam penelitiannya menyatakan bahwa likuiditas berpengaruh negatif terhadap struktur modal. Sedangkan penelitian yang dilakukan oleh Dharmadi dan Putri (2018), menemukan bahwa likuiditas berpengaruh positif terhadap struktur modal. Dahlena (2017), dalam penelitiannya menyatakan bahwa likuiditas tidak berpengaruh terhadap struktur modal.

Pertumbuhan penjualan adalah peluang pertumbuhan yang dimiliki perusahaan dimasa mendatang untuk mengembangkan perusahaannya. Perusahaan dapat melihat prospek yang akan didapatkan dimasa yang akan datang dengan melihat peluang dari pertumbuhan penjualan. (Dewi dan Dana, 2017). Sari (2017), dalam penelitiannya menyatakan bahwa growth tidak berpengaruh terhadap struktur modal. Wulandari dan Artini (2019) dalam penelitiannya menyatakan bahwa growth berpengaruh positif terhadap struktur modal. Kemudian Dewi dan Dana (2017), dalam penelitiannya menyatakan bahwa growth berpengaruh negatif terhadap struktur modal. 


\section{METODE}

Penelitian ini menggunakan pendekatan kuantitatif dengan bentuk asosiatif. Penelitian ini dilakukan untuk mengetahui pengaruh profitabilitas, likuiditas, pertumbuhan penjualan terhadap stuktur modal. Penelitian ini dilakukan pada sektor basic industry and chemical yang terdaftar di Bursa Efek Indonesia (BEI).

Metode yang digunakan dalam penelitian ini adalah purposive sampling dimana peneliti menentukan pengambilan sample dengan kriteria khusus yang sesuai dengan tujuan penelitian. 1). Perusahaan terdaftar di BEI tahun 2016-2019. 2). Perusahaan Industri dasar dan kimia yang tidak konsisten mempublish laporan keuangannya periode 20162019. 3). Perusahaan Industri dasar dan kimia yang menggunakan mata uang asing periode 2016-2019. 4). Perusahaan Industri dasar dan kimia yang mengalami kerugian periode 2016-2019.

Dalam penelitian ini, teknik analisis data yang digunakan adalah analisis regresi data panel dengan bantuan software pengolah data statistic yaitu Eviews 9.0. berikut adalah metode analisis data yang digunakan:

1. Analisis Statistik Deskriptif

Statistik deskriptif digunakan untuk memberikan gambaran untuk mendeskripsikan suatu data variabel yang dilihat dari nilai mean, nilai maksimum, minimum, dan standar deviasi dari satu variabel dependen dan tiga variabel independen.

2. Estimasi Regresi Data Panel

Menurut Sriyana (dalam Eksandy, 2018:21-26), model regresi data panel terbagi menjadi 3, yaitu:

a. Common Effects Model (CEM)

b. Fixed Effect Model (FEM)

c. Random Effect Model (REM)

3. Teknik Pemilihan Model Regresi Data Panel

Teknik pemilihan model regresi data panel terbagi menjadi 3, yaitu:

a. Uji Chow

Hipotesis dalam Uji Chow:

H0 : Model mengikuti Common Effect Model (CEM)

$\mathrm{Ha}$ : Model mengikuti Fixed Effect Model (FEM)

b. Uji Hausman

Hipotesis dalam Uji Hausman:

HO : Model mengikuti Random Effect Model (REM)

$\mathrm{Ha}$ : Model mengikuti Fixed Effect Model (FEM)

c. Uji Langrage Multiplier

Hipotesis dalam Uji Langrage Multiplier adalah:

HO : Model mengikuti Common Effect Model (CEM)

Ha : Model mengikuti Random Effect Model (REM)

4. Uji Asumsi Klasik

Menurut (Eksandy, 2018:77), Perlu atau tidaknya uji asumsi klasik tergantung pada hasil pemilihan estimasi model regresi. Dalam 
regeresi data panel model yang berbasis Ordinary Least Square (OLS) adalah Common Effect Model (CEM) dan Fixed Effect Model (FEM), dengan demikian perlu dilakukan uji asumsi klasik. Sebaliknya, apabila persamaan regresi lebih cocok menggunakan Random Effect Model (REM), maka tidak perlu dilakukan uji asumsi klasik.

5. Uji Hipotesis

a. Uji F

Uji $F$ digunakan untuk menjelaskan apakah variabel bebas mempunyai pengaruh terhadap variabel terikat, apabila uji $\mathrm{F}$ tidak berpengaruh maka penelitian tidak dapat dilanjutkan karena model penelitian tidak dapat menjelaskan adanya hubungan antar variabel.

Perbandingan $\mathrm{F}$ statistic dengan $\mathrm{F}$ tabel

$\mathrm{HO}$ : Jika F-statistic $<\mathrm{F}$ tabel

$\mathrm{Ha}$ : Jika F-statistic $>\mathrm{F}$ tabel

Berdasarkan Probabilitas

$\mathrm{HO}$ : Jika nilai Prob (F-statistic) $>$ a 0,05

$\mathrm{Ha}$ : Jika nilai Prob (F-statistic) $<\alpha 0,05$

b. Uji Koefisien Determinasi

Nilai $R$ - squared berada diantara 0 sampai 1 dengan penjelasan yaitu: 1). Nilai $R$-squared harus berkisar antara 0 sampai 1. 2). Jika nilai $R$-squared sama dengan 1 , berarti naik atau turunnya variabel terikat $(Y)$ 100\% dipengaruhi oleh variabel bebas $(X)$. 3). Jika nilai $R$-squared sama dengan 0 berarti, tidak ada hubungan sama sekali antara variabel independen terhadap variabel dependen.

c. Uji T

Uji t menjelaskan pengaruh variabel bebas secara parsial terhadap variabel terikat. Hipotesis dalam uji t adalah sebagai berikut:

Berdasarkan perbandingan t-statistic dengan t-tabel:

Ho: Jika nilai $t$-statistic $<$ t tabel

Ha: Jika nilai $t$-statistic $>$ t tabel

Berdasarkan probabilitas:

Ho: Jika nilai Prob $>0,05$

Ha: Jika nilai Prob $<0,05$

6. Analisis Regresi Data Panel

Menurut (Eksandy, 2018:45), analisis Regresi Data Panel merupakan gabungan antara data cross section dan data time series, dimana unit cross section yang sama diukur pada waktu yang berbeda. Maka dengan kata lain, data panel merupakan data dari beberapa individu (sampel) yang diamati dalam beberapa periode waktu tertentu. Persamaan Regresi Data Panel adalah sebagai berikut:

$$
Y_{i t}=\beta_{0}+\beta_{1} X_{1 i t}+\beta_{2} X_{2 i t}+\beta_{3} X_{3 i t}+\varepsilon_{i t}
$$


Dimana :

$\mathrm{Y}=$ Variabel Dependen

$\beta 0=$ Konstanta

$\beta 1,2,3=$ Koefisien Regresi Variabel Independen

$\mathrm{X} 1,2,3=$ Variabel Independen

$\mathrm{i} \quad=$ Perusahaan

$\mathrm{t} \quad=$ Waktu

HASIL

$\varepsilon \quad=$ Residual / Error

Analisis Statistik Deskriptif

Tabel 1. Analisis Statistik Deskriptif

Date: $11 / 06 / 20$

Time: 15:06

Sample: 20162019

\begin{tabular}{|c|c|c|c|c|}
\hline & DER & ROE & CR & GROWTH \\
\hline Mean & 1.067402 & 0.101976 & 2.235466 & 0.112618 \\
\hline Median & 0.855350 & 0.094700 & 1.631350 & 0.083300 \\
\hline Maximum & 5.442600 & 0.327700 & 7.719000 & 0.858900 \\
\hline Minimum & 0.109200 & 0.002000 & 0.704100 & -0.382500 \\
\hline Std. Dev. & 0.963054 & 0.063439 & 1.495646 & 0.195269 \\
\hline Skewness & 2.323035 & 0.649720 & 1.561666 & 1.187418 \\
\hline Kurtosis & 9.234690 & 3.398480 & 5.029675 & 6.023533 \\
\hline Jarque-Bera & 261.9817 & 8.005096 & 60.12406 & 64.05358 \\
\hline Probability & 0.000000 & 0.018269 & 0.000000 & 0.000000 \\
\hline Sum & 111.0098 & 10.60550 & 232.4885 & 11.71230 \\
\hline Sum Sq. Dev. & 95.52965 & 0.414531 & 230.4065 & 3.927372 \\
\hline $\begin{array}{l}\text { Observations } \\
\text { ce: Eviews 9.0, } 2020\end{array}$ & 104 & 104 & 104 & 104 \\
\hline
\end{tabular}

Berdasarkan tabel 2, nilai Mean atau rata-rata data terbesar dialami oleh variabel CR yaitu sebesar 2.235466, sementara ROE memiliki nilai mean terkecil yaitu sebesar 0.101976. Nilai Median atau nilai tengah terbesar dialami oleh CR yaitu sebesar 1.631350, dan nilai median terkecil dialami oleh Growth yaitu sebesar 0.083300. Nilai Maximum terbesar dialami oleh CR yaitu sebesar 7.719000, sementara ROE memiliki maximum terkecil yaitu sebesar 0.327700 . Nilai Minimum terbesar dialami oleh CR yaitu sebesar 0.704100 , sementara ROE memiliki minimum terkecil yaitu sebesar 0.002000 . Nilai Standar Deviation terbesar dialami oleh CR yaitu sebesar 1.495646, sementara ROE memiliki Std. Dev terkecil yaitu sebesar 0.063439. Positive Skewness menunjukan bahwa 
distribusi datanya memiliki ekor panjang disisi kanan. Semua variabel DER, ROE, CR dan Growth memiliki nilai positif. Untuk variabel DER, CR dan Growth memiliki nilai diatas 0 (nol), yang berarti bahwa asimetri distribusi data mean tidak mormal. Sedangkan variabel ROE memiliki nilai sekotar 0 (nol), yang berarti bahwa asimetri distribusi data disekitar mean bersifat normal. Kurtosis mengukur ketinggian suatu distribusi. Semua variabel DER, ROE, CR dan Growth memiliki nilai kurtosis lebih dari 3, yang berarti bahwa ketinggian distribusi data tidak normal atau dikatakan leptokurtis terhadap normal. Jarque-Bera adalah uji statistik untuk mengetahui apakah data berdistribusi normal. Uji ini mengukur perbedaan skewness dan kurtosis data dan dibandingkan dengan apabila datanya bersifat normal. Dengan HO pada data berdistribusi normal, uji JaqueBera didistribusi dengan X2 dengan derajat bebas (degree of freedom) sebesar. Probability menunjukkan kemungkinan nilai Jarque-Bera melebihi (dalam nilai absolut) nilai terobservasi di bawah hipotesis nol. Nilai probabilitas yang kecil cenderung mengarahkan pada penolakan hipotesis nol distribusi normal.

Pemilihan Model Regresi Data Panel

\section{Tabel 2. Uji Chow}

Redundant Fixed Effects Tests

Equation: Untitled

Test cross-section fixed effects

\begin{tabular}{lll}
\hline Effects Test Statistic & \\
\hline
\end{tabular}

\begin{tabular}{lrr}
\hline \hline & 8.13972 & \\
Cross-section F & 5 & $(25,75)$ \\
Cross-section Chi- & 136.438 & \\
square & 145 & 250.0000 \\
\hline \hline
\end{tabular}

Source: Eviews 9.0, 2020

Dalam tabel 2 terdapat nilai probabilitas Cross-section $\mathrm{F}$ adalah $0,00<\alpha(0,05)$ dan Cross-section Chi-square adalah $0,00<\alpha(0,05)$, maka Fixed Effect Model (FEM) lebih layak digunakan dibandingkan dengan Common Effect Model (CEM).

Tabel 3. Uji Hausman

Correlated Random Effects - Hausman

Test

Equation: Untitled

Test cross-section random effects

Test Summary Chi-Sq. Chi-Sq. Prob. 
Statistic d.f.

\begin{tabular}{lrr} 
& 4.64436 & \\
\hline \hline Cross-section random & 9 & 30.1998 \\
\hline \hline
\end{tabular}

Source: Eviews 9.0, 2020

Dari tabel 3 terlihat nilai probabilitas Cross-section Random adalah $0,1998>\alpha(0,05)$, maka dapat disimpulkan bahwa Random Effect Model (REM) lebih layak digunakan dibandingkan dengan Fixed Effect Model (FEM).

Tabel 4. Uji Langrage Multiplier

Lagrange Multiplier Tests for Random Effects

Null hypotheses: No effects

Alternative hypotheses: Two-sided (Breusch-Pagan)

and one-sided

(all others) alternatives

\begin{tabular}{|c|c|c|c|}
\hline & \multicolumn{3}{|c|}{ Test Hypothesis } \\
\hline & $\begin{array}{l}\text { Cross- } \\
\text { section }\end{array}$ & Time & Both \\
\hline Breusch-Pagan & $\begin{array}{l}57.18691 \\
(0.0000)\end{array}$ & $\begin{array}{l}1.978774 \\
(0.1595)\end{array}$ & $\begin{array}{c}59.16568 \\
(0.0000)\end{array}$ \\
\hline
\end{tabular}

Source: Eviews 9.0, 2020

Berdasarkan tabel 4, nilai probabilitas Cross-section BreuschPagan $0.00<$ a (0.05), maka disimpulkan bahwa Random Effect Model (REM) lebih layak digunakan dibandingkan dengan Common Effect Model (CEM).

Tabel 5. Kesimpulan Model

\begin{tabular}{clll}
\hline No & Metode & Pengujian & Hasil \\
\hline $\mathbf{1}$ & Uji Chow & CEM vs FEM & FEM \\
\hline $\mathbf{2}$ & Uji Hausman & REM vs FEM & REM \\
$\mathbf{3}$ & $\begin{array}{l}\text { Uji Langrage } \\
\text { Multiplier }\end{array}$ & CEM vs REM & REM \\
\hline
\end{tabular}

Berdasarkan hasil ketiga pengujian yang sudah dilakukan maka dapat disimpulkan bahwa Model Regresi Data Panel yang akan digunakan dalam uji hipotesis dan persamaan regresi Data Panel adalah model Random Effect Model (REM). 
Uji Hipotesis

\section{Tabel 6. Random Effect Model}

Dependent Variable: DER

Method: Panel EGLS (Cross-section random effects)

Date: 01/08/21 Time: 18:48

Sample: 20162019

Periods included: 4

Cross-sections included: 26

Total panel (balanced) observations: 104

Swamy and Arora estimator of component variances

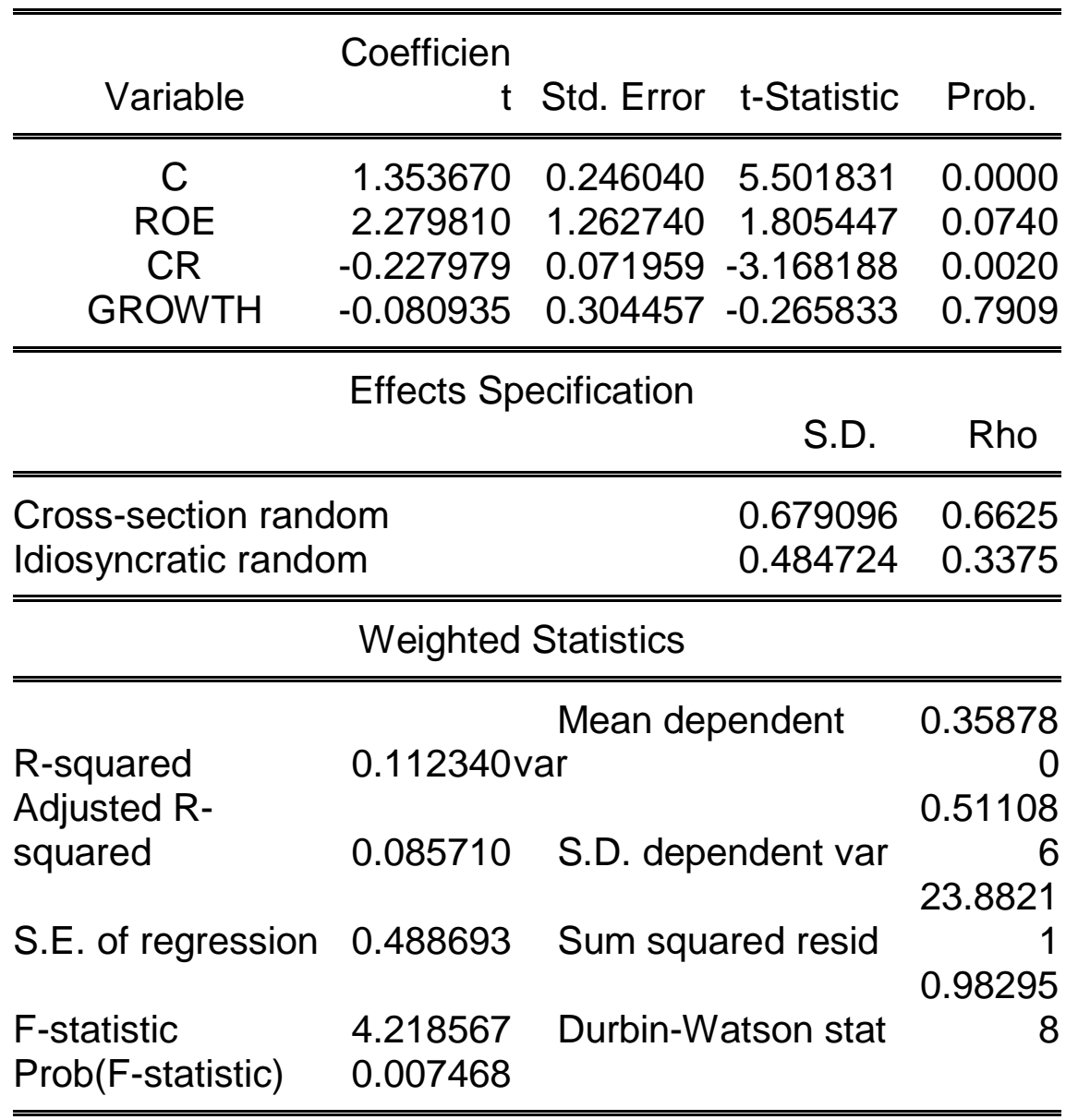

Source: Eviews 9.0, 2020

Berdasarkan tabel 6, menunjukan bahwa F-statistic sebesar 4,218567 , sementara $F$ Tabel dengan tingkat $\alpha=5 \%$, df1(k-1) $=3$ dan df2 $(\mathrm{n}-\mathrm{k})=100$ diddapat nilai $\mathrm{F}$ Tabel sebesar 2,695534. Dengan demikian Fstatistic (4.218567) > F Tabel (2,695534) dan nilai Prob(F-statistic) $0,007568<0,05$ maka dapat disimpulkan bahwa Ha diterima, yang artinya 
variabel-variabel independen dalam penelitian ini secara bersama-sama memiliki pengaruh terhadap struktur modal.

Berdasarkan tabel 6, menunjukan bahwa hasil uji Adjusted $R$ squared sebesar 0,085710 artinya bahwa perubahan naik turunnya struktur modal dapat dijelaskan oleh Profitabilitas, Likuiditas dan Pertumbuhan Penjualan sebesar $8,57 \%$, sementara sisanya sebesar $91,42 \%$ dijelaskan oleh variabel-variabel yang tidak diteliti dalam penelitian ini.

Nilai $t$-statistic Profitabilitas (ROE) sebesar 1,805447, sementara t Tabel dengan tingkat $\alpha=0,05$ atau $5 \%$, df $(n-k)=100$ didapat nilai tabel 1,983971519. Dengan demikian t-statistic $(1,805447)<\mathrm{t}$ Tabel $(1,983917159)$ dan nilai Prob. $0,0740>0,05$, karena tingkat signifikan lebih besar dari a maka $\mathrm{H} 1$ ditolak. Sehingga dapat disimpulkan bahwa profitabilitas tidak berpengaruh terhadap struktur modal.

Nilai $t$-statistic Likuiditas (CR) sebesar $-3,168188$, sementara $\mathrm{t}$ Tabel dengan tingkat $\alpha=0,05$ atau $5 \%$, df $(n-k)=100$ didapat nilai tabel 1,983971519. dengan demikian $t$-statistic $(3,168188)>t$ Tabel $(1,983971519)$ dan nilai Prob. $0,0020<0,05$, karena tingkat signifikan lebih kecil dari $\alpha$, maka $\mathrm{H} 2$ diterima. Sehingga dapat disimpulkan bahwa likuiditas berpengaruh terhadap struktur modal.

Nilai $t$-statistic Pertumbuhan Penjualan (Growth) sebesar 0,265833 , sementara $t$ Tabel dengan tingkat $\alpha=0,05$ atau $5 \%$, df $(n-k)=$ 100 didapat nilai tabel 1,983971519. dengan demikian $t$-statistic $(0,265833)<\mathrm{t}$ Tabel $(1,983971519)$ dan nilai Prob. 0,7909 > 0,05, karena tingkat signifikan lebih besar dari a maka H3 ditolak. Sehingga dapat disimpulkan bahwa pertumbuhan penjualan tidak berpengaruh terhadap struktur modal.

Persamaan Model Regresi Data Panel

$\mathrm{Y}=1.353670+2.279810 \mathrm{ROE}-0.227979 \mathrm{CR}-0.080935 \mathrm{GROWTH}+\varepsilon$

Persamaan regresi data panel mempunyai penjelasan sebagai berikut:

Nilai konstanta $=1.353670$ bernilai positif. Hal ini menunjukan bahwa jika variabel independen tidak ada atau bernilai 0 (nol), maka nilai struktur modal sebesar 1.353670. Nilai koefisien regresi variabel profitabilitas (ROE) sebesar 2.279810. Hal ini menunjukan bahwa semakin besar profitabilitas, maka stuktur modal semakin tinggi. Nilai koefisien regresi variabel likuiditas $(\mathrm{CR})$, sebesar - 0.227979. Hal ini menunjukan bahwa semakin besar likuiditas, maka struktur modal semakin rendah. Nilai koefisien regresi variabel pertumbuhan penjualan (Growth), sebesar - 0.080935. Hal ini menunjukan bahwa semakin besar pertumbuhan penjualan, maka struktur modal semakin rendah.

Interpretasi Hasil 
Berdasarkan uji t (parsial) menunjukan koefisien sebesar 1,805447 dengan tingkat signifikan sebesar $0,0740>\alpha=0,05$. Karena tingkat signifikan lebih besar dari $\alpha=0,05$, maka $\mathrm{H} 1$ ditolak. Sehingga kesimpulannya adalah profitabilitas (ROE) tidak berpengaruh terhadap struktur modal. Hal ini menunjukan bahwa semakin besar tingkat profitabilitas suatu perusahaan maka akan menyebabkan struktur modal menjadi rendah. Hasil penelitian ini juga sejalan dengan penelitian yang dilakukan oleh (Septiani dan Suaryana, 2018) profitabilitas tidak berpengaruh terhadap struktur modal.

Berdasarkan uji $t$ (parsial) menunjukan koefisien negatif sebesar 3,168188 dengan tingkat signifikan sebesar $0,0020<\alpha=0,05$. Karena tingkat signifikan $<\alpha=0,05$, maka $\mathrm{H} 2$ diterima. Sehingga kesimpulannya adalah likuiditas (CR) berpengaruh negatif terhadap struktur modal. Hal ini menunjukan bahwa kondisi tersebut dapat terjadi karena perusahaan yang memiliki tingkat likuiditas yang tinggi maka akan memiliki dana internal yang tinggi sehingga, perusahaan akan cenderung menggunakan dana internal yang dimilikinya bukan dari pendanaan eksternal. Hasil penelitian ini sejalan dengan penelitian yang dilakukan oleh (Septiani dan Suaryana, 2018) yang menyatakan bahwa likuiditas berpengaruh negatif terhadap struktur modal.

Berdasarkan hasil uji $\mathrm{t}$ (parsial) menunjukan koefisien negatif sebesar -0,265833 dengan tingkat signifikan sebesar 0,7909 > $\alpha=0,05$. karena tingkat signifikan lebih besar dari $\alpha=0,05$, maka $\mathrm{H} 3$ ditolak. Sehingga kesimpulannya adalah pertumbuhan penjualan tidak berpengaruh terhadao struktur modal. Hal ini menunjukan bahwa tinggi atau rendahnya tingkat pertumbuhan penjualan belum tentu berpengaruh terhadap struktur modal. Hasil penelitian ini sejalan dengan penelitian yang dilakukan (Sari, 2017), yang menyatakan bahwa pertumbuhan penjualan tidak berpengaruh terhadap struktur modal.

Penelitian ini memiliki beberapa keterbatasan yaitu:

Periode pengamatan dalam penelitian ini memiliki waktu yang sangat singkat, memiliki rentang waktu 4 tahun dari tahun 2016 2019Penelitian ini hanya menggunakan data populasi pada sektor industri dasar dan kimia yang terdaftar di Bursa Efek Indonesia (BEI). Dalam pengambilan data beberapa perusahaan mengalami kerugian.

\section{KESIMPULAN}

Berdasarkan rumusan masalah dari hasil penelitian yang telah diuraikan, kesimpulan dari penelitian ini adalah profitabilitas yang diukur dengan return on equity tidak berpengaruh terhadap struktur modal yang diukur dengan debt to equity ratio. Likuiditas yang diukur dengan Current Ratio berpengaruh negatif dan signifikan terhadap struktur modal yang diukur dengan debt to equity ratio. Pertumbuhan penjualan diukur dengan perubahan penjualan setiap tahunnya tidak berpengaruh terhadap struktur modal yang diukur dengan debt to equity ratio. 
Dari penelitian yang sudah dijelaskan diatas diharapkan dapat digunakan sebagai bahan informasi untuk penelitian lebih lanjut dimasa yang akan datang. Penelitian selanjutnya diharapkan memasukan variabel-variabel lain yang dapat mempengaruhi struktur modal dan memasukan faktor-faktor yang memperkuat struktur modal. Diharapkan agar menambah periode penelitian atau menggunakan data dari sektor lain yang digunakan sebagai objek penelitian.

\section{DAFTAR PUSTAKA}

Eksandy, A. (2018). Metode Penelitian Akuntansi Dan Manajemen (Mohamad Zulman Hakim (Ed.)). FEB UMT.

Dharmadi, I. K. Y., Ayu, I. G., Asri, M., \& Putri, D. (2018). E-Jurnal Akuntansi Universitas Udayana Pengaruh Struktur Aset , Profitabilitas, Operating Leverage, Likuiditas Terhadap Struktur Modal Perusahaan Consumer Goods Di BEl Fakultas Ekonomi Dan Bisnis Universitas Udayana ( Unud ), Bali , Indonesia Perkembang. 24, 1858-1879.

Intan Apsari, G. A. P., \& Dana, I. M. (2018). Pengaruh Profitabilitas, Struktur Aktiva Dan Size Terhadap Struktur Modal Pada Perusahaan Barang Konsumsi DI BEI. E-Jurnal Manajemen Universitas Https://Doi.Org/10.24843/Ejmunud.2018.V07.I12.P17

Udayana.

Putu, N., \& Wulandari, I. (2019). Pengaruh Likuiditas, Non-Debt Tax Shield, Ukuran Perusahaan Dan Pertumbuhan Penjualan Terhadap Stuktur Modal. Fakultas Ekonomi Dan Bisnis Universitas Udayana ( Unud ), Bali , Indonesia 8(6), 3560-3589.

Melinda Sari, T. A. (2020). Pengaruh Komisaris Asing Dan Direksi Asing Terhadap Struktur Modal. Ekuitas (Jurnal Ekonomi Dan Keuangan). Https://Doi.Org/10.24034/J25485024.Y2019.V3.14.4196

Deviani, M. Y., \& Sudjarni, L. K. (2018). Pengaruh Tingkat Pertumbuhan, Struktur Aktiva, Profitabilitas, Dan Likuiditas Terhadap Struktur Modal Perusahaan Pertambangan DI BEl. E-Jurnal Manajemen Universitas Https://Doi.Org/10.24843/Ejmunud.2018.V7.I03.P04

Udayana.

Dewi, N., \& Dana, I. (2017). Pengaruh Growth Opportunity, Likuiditas, Non-Debt Tax Shield Dan Fixed Asset Ratio Terhadap Struktur Modal. E-Jurnal Manajemen Universitas Udayana.

Susantika, B., \& Mahfud, M. K. (2019). Profitabilitas Sebagai Variabel Intervening (Studi Pada Perusahaan Manufaktur Sektor Aneka Industri Yang Terdaftar Di Bursa Efek Indonesia Tahun 2012-2016). Journal Of Management.

Nst, M. D. (2017). Pengaruh Likuiditas, Risiko Bisnis Dan Profitabilitas Terhadap Struktur Modal Pada Perusahaan Textile Dan Garment Yang Terdaftar Di Bursa Efek Indonesia. Jurnal Riset Akuntansi \& Bisnis.

Oktaviantari, N. K. A., \& Baskara, I. G. K. (2019). Pengaruh Ukuran 
Perusahaan, Tangibility Assets, Dan Kepemilikan Manajerial Terhadap Struktur Modal Pada Sub Sektor Ritel. E-Jurnal Manajemen Universitas Udayana. https://doi.org/10.24843/ejmunud.2019.v08.i06.p20

Rahkutin, R., \& Alwi, A. (2020). Pengaruh Return On Assets dan Ukuran Perusahaan Terhadap Struktur Modal PT.Mayora Indah Tbk. Capital: Jurnal Ekonomi Dan Manajemen. https://doi.org/10.25273/capital.v4i1.7360

Panggabeam, V. D. Y., Inrawan, A., Silitonga, H. P., \& Sembiring, L. D. (2019). Dampak Struktur Aset Dan Ukuran Perusahaan Terhadap Struktur Modal. Sultanist: Jurnal Manajemen Dan Keuangan. https://doi.org/10.37403/sultanist.v7i2.157

Www.Idx.Co.Id. (N.D.).

Www.Academia.Edu/5677676/Tabel-F 